\title{
CAMP-Responsive Element-Binding Protein-Like 2
}

National Cancer Institute

\section{Source}

National Cancer Institute. CAMP-Responsive Element-Binding Protein-Like 2. NCI

Thesaurus. Code C25844.

CAMP-responsive element-binding protein-like 2 (120 aa, $14 \mathrm{kDa}$ ) is encoded by the human CREBL2 gene. This protein plays a role in the regulation of both transcription and signaling. 